\title{
Tarlabaşı, Istanbul: a case study of unsustainable urban transformation
}

\author{
M. L. Turanalp Uysal ${ }^{1} \&$ N. Korostoff ${ }^{2}$ \\ ${ }^{1}$ Independent Researcher, Boston, USA \\ ${ }^{2}$ Department of Landscape Architecture, Penn State University, USA
}

\begin{abstract}
The purpose of this paper is to examine a municipally sponsored urban transformation project in the Tarlabaşı neighbourhood of central Istanbul, Republic of Turkey, the first modern urban area of the city, for its effects on the historic, social, cultural and economic sustainability of the city. The study examines the 300-year history of the neighbourhood and its most recent social and physical conditions prior to the transformation project (which is currently under way). Historic records, maps, plan and photographs will be utilized in the study. The results of the study demonstrate that the urban renewal project imposed upon the Tarlabaşı community by the municipality and allied agencies is not sustainable. To the contrary, the project has destroyed a culturally rich and socially diverse community with deep roots in the historic urban texture of Istanbul and destabilized adjacent communities. It has displaced over 4,000 people; added to the homeless population of central Istanbul; and created additional pressure on impoverished areas nearby. The physical transformation of the area will destroy all but the facades of over 210 (of 278) historically registered buildings and completely altered the spatial configuration from a $16^{\text {th }}$ century neighbourhood of two and three story buildings on narrow streets and alleys to a $21^{\text {st }}$ century zone of gleaming glass and steel condominiums. From a socially diverse community providing refuge and employment for minorities and those with alternative lifestyles, Tarlabaşı will become a bedroom zone for the newly rich of Istanbul. In the conclusion of the study the authors will discuss the impact of several similar urban transformation projects upon the sustainability of historic central Istanbul. Keywords: sustainability, gentrification, urbanization, urban health.
\end{abstract}




\section{Introduction}

The world's population living in the cities has been increasing dramatically in the last few decades. Today, the population of the world is more than seven billion. It is estimated that $54 \%$ of the world's population is currently living in urban areas where more than one billion people have been added since 2000 [1-3]. This large influx of population resulted in unplanned urbanization, which does not provide a sustainable life for urban dwellers due to social, economic, ecological, and public health problems.

On one hand, there is a significant increase of the global population causing serious problems affecting urban and public health. On the other hand, there are continuing discussions about the solutions to this rapid population growth and the provision of sustainable. The number of urban residents is growing by nearly 60 million every year. This demographic transition from rural to urban, or urbanization, has far-reaching consequences. Because so many new urban residents are drawn from the rural poor, many speak about the "urbanization of poverty" in the $21^{\text {st }}$ century [1-3].

Urbanization has been connected with overall shifts in the economy especially towards mass industry, technology and service and away from agricultural and manufacturing [4]. High urban densities have reduced transaction costs, made public spending on infrastructure and services more economically practical, and enabled production and circulation of information, all of which have encouraged growth strategies with a specific focus on the service and knowledge economies [3].

One widely promoted solution to the perceived need for economic growth is the creation "mega cities" - super-large urban areas that supposedly answer the need for growth through size alone [5]. Istanbul could be a case study to analyse and understand the challenges of rapid population growth and consumption in spontaneously urbanized areas. For instance, as seen in the figure 1, after the construction of second Bosporus Bridge in 1988, urbanization spread dramatically towards north, a formerly preserved ecological area protecting the city's important watersheds. After the first Bosporus Bridge, 1973, the population was around 2.5 million, after the second one the population dramatically increased to 6.5 million. Finally, the third Bosporus Bridge is current being constructed and the population is over 15 million [6].

With a population nearing 16 million and a total land area of approximately 1,930 square miles, it has been estimated that, at current growth rates, the city could have as many as 17 million inhabitants by 2023 [7]. Istanbul has been a centre of art, design, architecture, trade, and business for an emerging creative class of young artists for the last few decades that make city even more desirable for construction companies as well as developers and government itself.

These cultural and economic conditions attract developers and government to build a more modern urban environment for the urban elites, which has resulted in extensive destruction of historic neighbourhoods of Istanbul during the last two decades. The tools for changing the city are "urban renewal projects" and "large urban scale developments" supported by national and municipal policies [8]. 


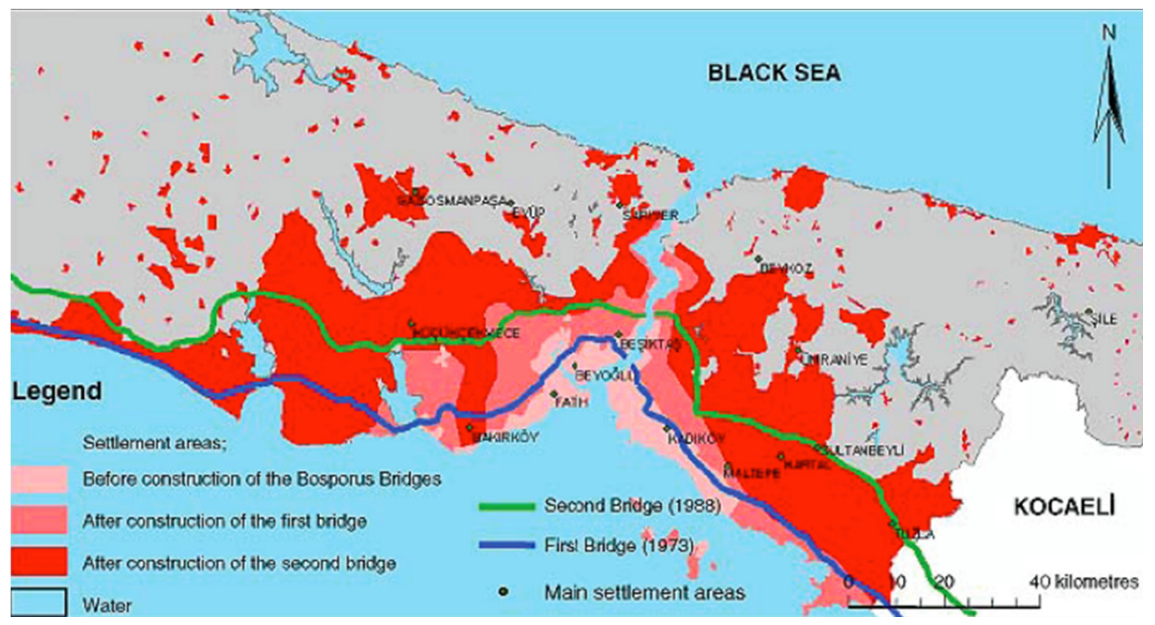

Figure 1: Istanbul growth.

Urban renewal projects that facilitate automobile ownership and displace poor urban residents, such as Tarlabaşı and Sulukule Renewal Projects, are widely known for their social, cultural and architectural transformations at enormous scale. The Tarlabaşı Urban Renewal Project is an important case study of this global problem of government and private developer sponsored urban transformations that benefit the wealthy urban elite and further disadvantage the city's massive impoverished population.

\section{Tarlabaşı}

Tarlabaşı is a neighbourhood that located in the northern part of İstanbul, right next to Taksim Square and Gezi Park in Central Istanbul, Turkey.

As you see in the figure 2, Tarlabaş1 is located in the centre of Istanbul, where the real estate is very highly valued.

\subsection{History of Tarlabaşı}

Tarlabaşı was a Muslim cemetery during the $17^{\text {th }}$ century. At the beginning of $18^{\text {th }}$ century, due to the growing population of Istanbul, Tarlabaşı became a new trade centre for non-Muslim citizens as it was outside of the historic centre of the old city. The old city or Holy City, the site of royal mosques and the Caliphate in the Ottoman Period (1453-1910) and the earlier Byzantine Empire of Constantinople on the far side of the Golden Horn waterway, excluded non-Muslims from residence. Following the tragic city fire of 1870, Tarlabaşı became a first planned portion of Istanbul. It became the centre of European urbanization in the city including hotels, theatres, wide roads and even a town square. In the second half of $19^{\text {th }}$ century, Tarlabaşı became a new residential area for the middle income and low-income class, while the other neighbourhoods around Tarlabaşı were the high- 


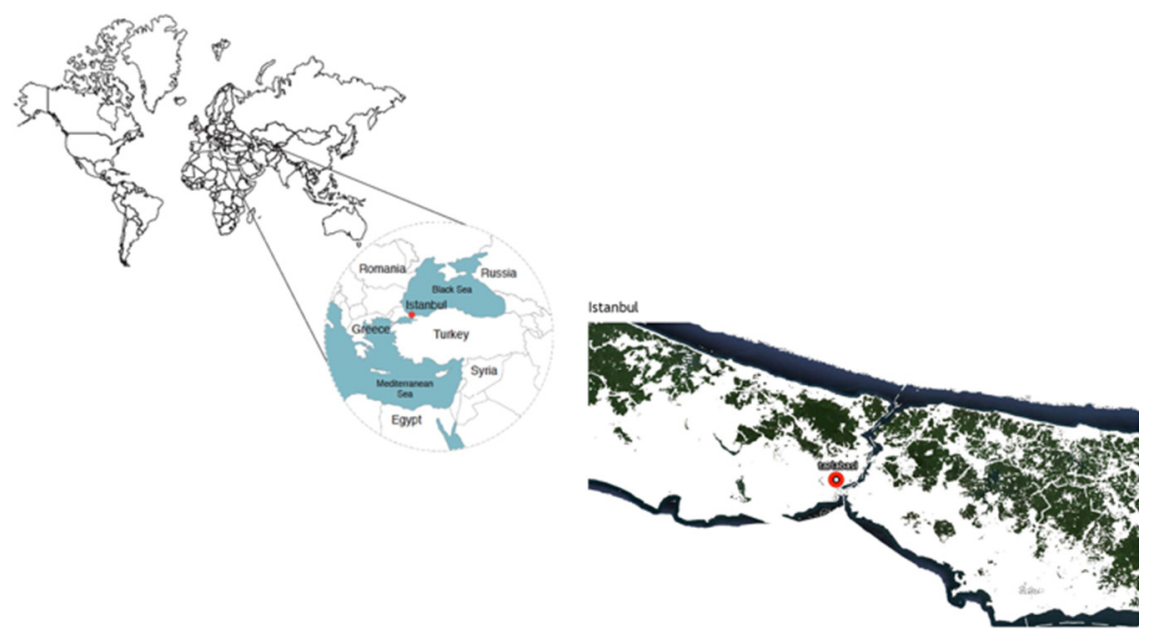

Figure 2: Istanbul and Tarlabaş1's location map.

class residential area. Tarlabaşı was a place of non-Muslim people including Jews, Armenians and Greeks excluded from the Holy City or historic area [9]. During World War I the Ottoman Empire allied itself with Germany and the AustroHungarian Empire and following its defeat the Ottoman Empire ceased to exist. In 1923 the new Republic of Turkey was created in the Anatolian heartland of the Turkish people but the cosmopolitan city of Istanbul fell from favour as Kemalist nationalism emphasized the new Republican capitol of Ankara.

In 1940s, under the influence of German racial ideology, the Republican government imposed wealth taxes upon non-Muslim citizens concentrated in urban enclaves such as Tarlabaşı. Non-Muslims who could or would not pay the wealth tax (60\% of all property) were deported to labour camps in the interior of the country. Though the wealth tax was later reversed, many of the residents of Tarlabaşı either sold their properties or low value or gave a power of attorney to local Turkish lawyers for renting these units and emigrated from Turkey during the 1950s [10].

Between 1960 and 1990 many of these housing units in Tarlabaş1 were rented to students and low-income workers. The residential units were over-populated due to illegal rental practices and deteriorated rapidly due of excessive use and lack of maintenance and investment [10]. During the 1990s, Kurdish citizens of eastern Turkey, seeking greater freedom and autonomy, were persecuted and attacked by the central government in a secret campaign that amounted to a form of civil warfare. Over 40,000 Turks and Kurds perished tragically during this period. Many Kurdish citizens of eastern Turkey moved to Tarlabaşı and other urban enclaves to escape violence in the rural areas and seek better opportunities in the city. Conditions deteriorated as more Kurds and other marginalized social groups crowded into the semi-feral neighbourhoods such as Tarlabaşı where gangs controlled the streets and even the police were afraid to venture at night. 


\subsection{Social and economical structure}

In the $20^{\text {th }}$ century, Tarlabaş 1 became a new mixed-use area for different ethnic groups such as Greeks, Armenians, nomads, Kurds, and Assyrians. Many domestic and international students rented cheap accommodations in the neighbourhood and it was known to harbour marginalized groups such as homosexuals, drug addicts and dealers and others who leaved on the fringes of society [11]. Towards the end of the century aftermath of non-Muslim ethnic groups being forced out and forced migration of Kurdish into the neighbourhood, the composition of the neighbourhood became more heavily Kurdish and nomads. Most of these people were low-income groups such as low-paid service workers, paper collectors, students, construction workers, and street hawkers. Families relied heavily upon their children's labour for income, the source of living for the $57 \%$ of families were their working children. $90 \%$ of women were illiterate and unemployed while the rest were working as housekeepers [12].

Tarlabaşı has been denounced publicly by the government as a criminal area, the centre of prostitution and drug trade in 2000s.

\section{Tarlabaşı project}

Tarlabaşı Renewal Project is the first of its kind in Turkey that is being processed by public-private sector cooperation with the ostensible goal of restoring the historical buildings and renovating the other buildings around in a modern architecture style [13]. The locally governing Beyoglu municipality announced the renewal project at February 2006 by publishing the project details quickly without the required public comment period. According to the municipality, though Tarlabaşı was a culturally rich neighbourhood, it was also not a safe zone in which to live. Strangely, Beyoglu municipality focused on a restoration project plan that promised to protect the original facades of the unique historical buildings by giving them a contemporary and modern appearance [14, 15]. Beyoglu Municipality's partner company, the Gap Insaat developer and construction company, is an important financial supporter of the ruling AKP political party. Gap Insaat articulated the goal of turning Tarlabaşı into a contemporarily designed modern exemplar of private sector construction. Their goal of a mixed-used urban development, with ground floor retail and commercial space and high-end residences on upper floors, mirrors contemporary urbanism in cities in Western Europe and the US. However both the architectural style and the type of urban development are totally foreign to the historic architectural and social context of Istanbul, Tarlabaşı and the Turkey [16].

In the figures 3-5, you can see that the characteristics of the historic buildings are mainly covered by modern architectural style as exemplified below.

\subsection{Project objectives and details}

The overall project area contains 21 blocks in the $20,000 \mathrm{~m}^{2}$ of the neighbourhood. The first part of the project is focused on renovations of 210 of 278 buildings in the 9 blocks [12]. 

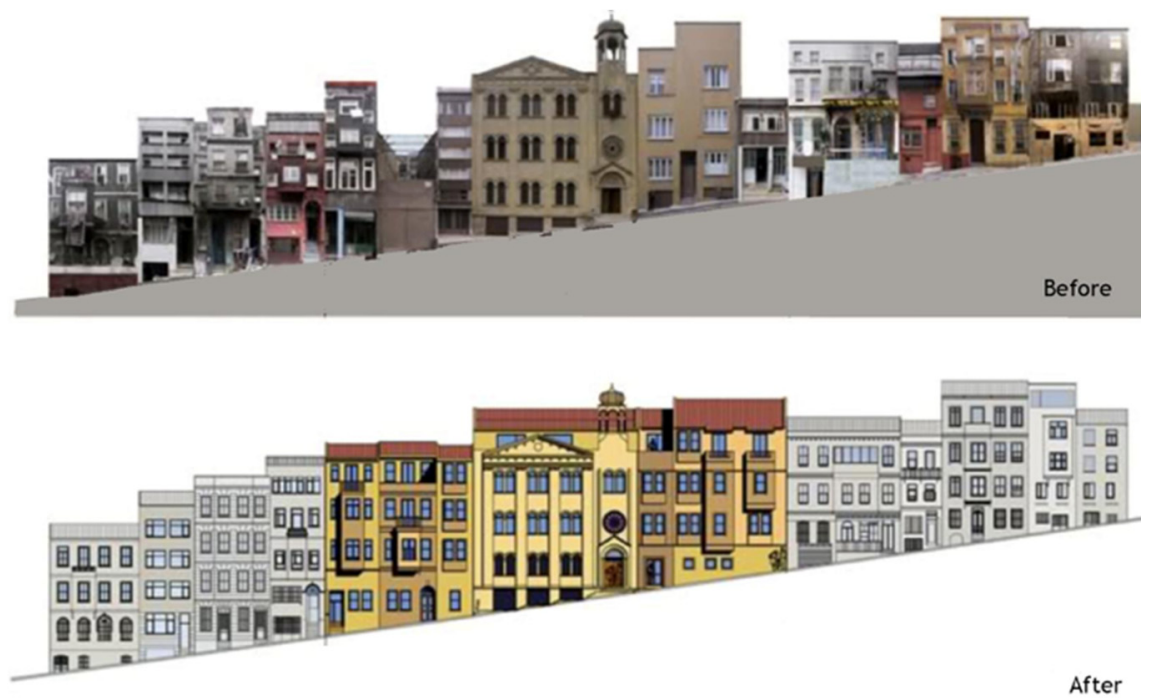

Figure 3: Tarlabaşı project drawings.

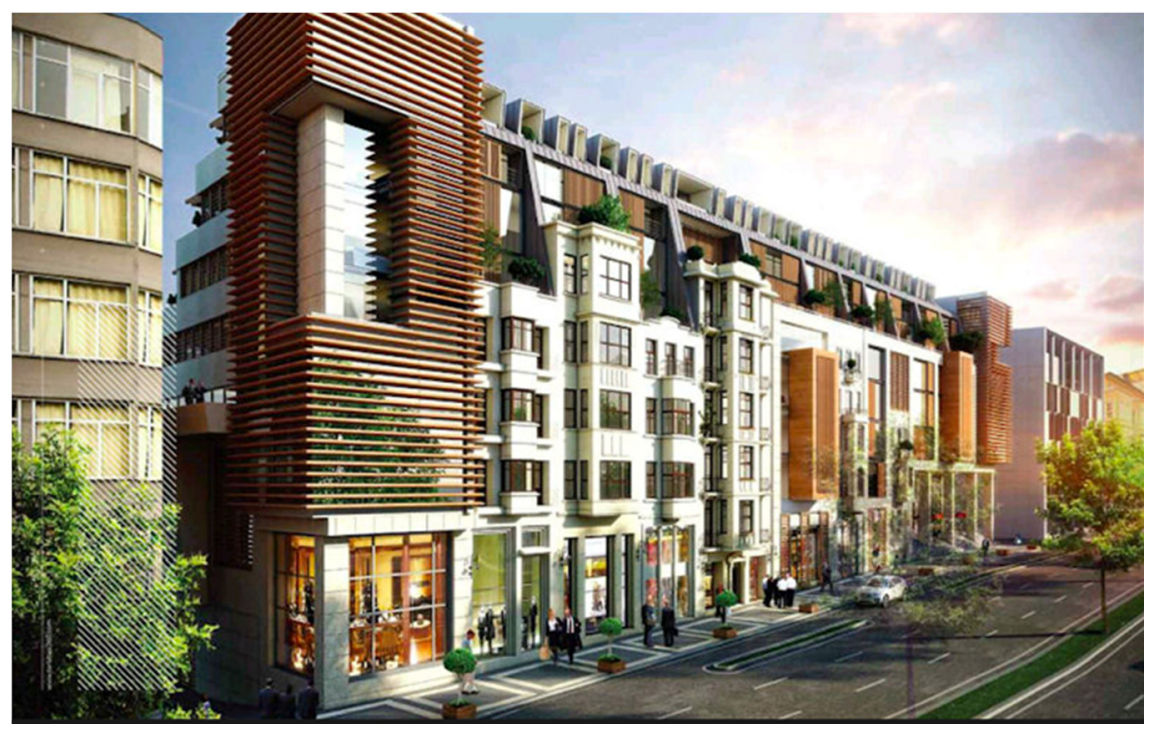

Figure 4: Tarlabaşı project drawings. 

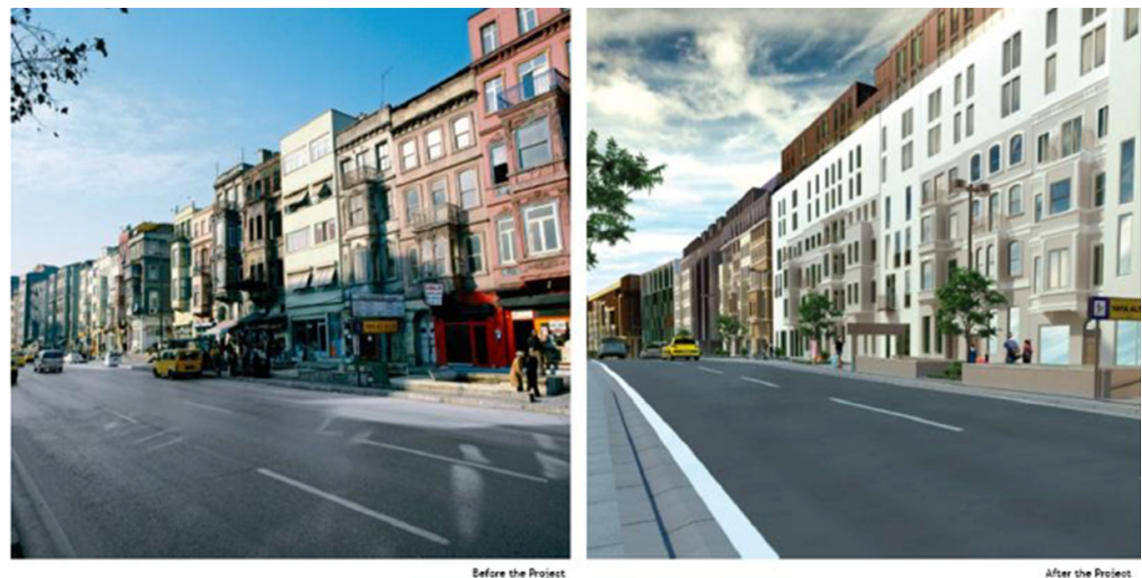

Figure 5: Tarlabaşı project drawings.

This renovation project specifically focused on protecting the historical identity of the buildings.

\section{THE GOALS OF THE RENOVATION PROJECT}

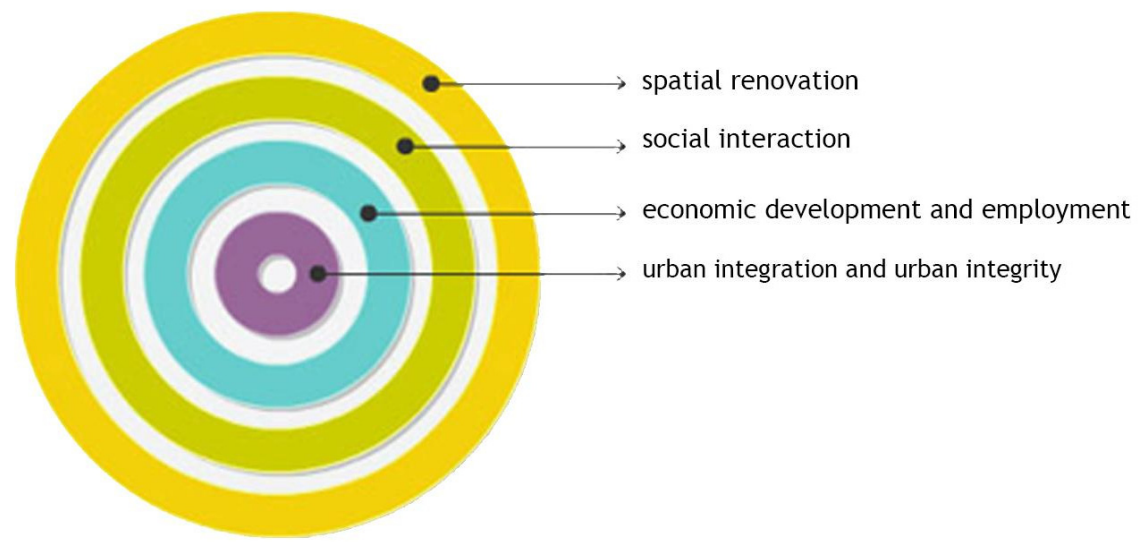

Figure 6: The goals of the Tarlabaşı renovation project.

Some of the main goals of the project as articulated by the municipality and the development company are outlined below [12]:

$>$ Integrate Tarlabaşı with Istanbul by changing it into a safer and healthier neighbourhood;

> Protect the architectural, cultural, environmental and historical values of the neighbourhood;

$>$ Provide a financial support from private sector in this public and private sector partnership; 
$>$ Improve transportation and infrastructure of the neighbourhood;

$>$ Increase the social well-being and the quality of life within the city.

\section{Today's Tarlabaşı}

The Cultural and Natural Properties Preservation Committee of Istanbul registered the historical buildings of Tarlabaşı a second time as culturally significant 2005, though they were already registered as such in 1978. Following this decision, Beyoglu municipality announced Tarlabaşı as the first Renewal Project of Turkey under the law 5633, the Renovation Law, in 2006, which declared that Tarlabaşı's historical buildings could be renovated and demolished if needed. Based upon the 1978 and 2005 registration process, those historic buildings should have been under the law's protection, which means that nothing could be changed in, around and on them without any permission. In the years following 2006, 18 out of 20 historic buildings on the main Tarlabaşı Boulevard were completely demolished. As for the rest of 210 historical buildings in the neighbourhood, only their facades were protected while the main part of the structures were demolished in order to be rebuilt as multi-use residences with five to six times the volume of the original buildings $[14,17]$.

Although the project was originally planned to be completed in 2010 , it is currently still be constructed with completion scheduled for 2017. There is no clear information published about the project by the leading company or the Beyoglu municipality. The streets are now empty of people in Tarlabaşı's Renewal Project Area. The metal shields cover all the streets entrances like a neighbourhood under siege.

The because most of the local population of Tarlabaşı did not own the properties they lacked rights and were forced to leave, either paid off with negligible monies, of less than fair value, or evicted by the local police forces. This once a multicultural neighbourhood lost its ethnic composition, diversity and population.

The leading construction company, Calik Holding-Gap Insaat, did not keep their promises to locals to provide replacement housing nearby. Thus, hundreds of families were forced to leave for far distant neighbourhoods though they were employed in the service sector in the city's centre.

\section{Conclusion}

Due to population growth and migration into cities, everyday local governments face the difficult management challenges of unplanned urbanization and the urbanization of poverty $[18,19]$. Municipalities and even national governments lack sufficient resources and organizational capacity to construct the necessary infrastructure and public services to provide safe and healthy living systems to their populations. It is often the case that poverty is concentrated in unplanned neighbourhoods as the rural poor flood into the urban periphery and remaining open spaces [18]. Today more than one billion people are live in urban slums. Most of them lack access to public health services, experience social and 
economical inequalities, and are marginalized in various ways $[2,18]$. This is an unhealthy and unsustainable situation of global dimensions. Though municipalities and national governments are aware of this many of the urban renewal or development projects they use to address the issues are problematically ineffective. Indeed, some of these urban renewal projects are poorly designed worsen the seriously unsustainable conditions [20]. Tarlabaşı project is a prime example for this type of faulty renewal projects. One can only conclude that the Tarlabaşı Urban Renewal Project, despite its claims, was never intended to benefit the poor and ethnic minority population of the neighbourhood. The actual intention of the project was to evict the poor and powerless and claim choice real estate for the wealthy global elites.

In contradiction to its original objectives, the renewal project did not deliver an ecological, economical, cultural, social and healthier living model for its original citizens. As defined in the renewal mission, social interaction within the community did not increase but actually disappeared as the locals were forced out of the neighbourhood. Another goal of the project was to create a safe and healthy environment for the locals, Tarlabaşı renewal project was meant to create such improved neighbourhood not for the original local population but for the new incoming wealthy class. The dramatic jump in house prices was a clear evidence for that. The housing prices increased over 40 fold, which clearly meant that the original poor locals would not be able to afford and thus would not be able to call Tarlabaş1 their home anymore. And the worst is what happened to the ethnic and cultural diversity, which was heavily advertised by the project as the neighbourhood's unique character and selling point. This rich diversity was destroyed as the original local population was forced to sell their homes or literally forced out of the neighbourhood.

\section{References}

[1] WHO-UN-Habitat, Global Forum on Urbanization and Health: 2010 Annual Report, Japan, 2010.

[2] WHO-Metropolis, Cities for Health, Hyderabad, India, 2014.

[3] World Health Organization Website: www.who.int

[4] Bauman, Z. Küreselleşme, Toplumsal Sonuçları, Istanbul, 1999.

[5] Soja, E. W., Six Discourses on the Postmetropolis, Sallie Williams \& John Williams (eds): Imagining Cities, London \& NY 1997.

[6] Turkish Ministry of Environment and Urbanization Website: www.csb.gov.tr

[7] Turkish Statistical Institute Website: www.turkstat.gov.tr

[8] Küçük, A.A., Küreselleşme ve Tarihi Alanlarda Dönüşüm: İstanbulTarlabaşı örneği, Istanbul, 2010.

[9] Kortun, V., 19. yy Pera ve Galata'daki Sosyal ve Kültürel Yaşam Dergisi 93/1, Istanbul, pp. 21-22, 1993.

[10] Savaşan, D., Kentsel Yarılmanın Kent Kimliğine Etkisi: Tarlabaşı Orneği, Istanbul, 2007.

[11] Mimarist, www.mimarist.org 
[12] Tarlabaşı 360, http://www.tarlabasi360.com.tr

[13] Beyoglu Municipality Website: www.beyoglu.bel.tr

[14] Yapi, www.yapidergisi.com

[15] Arkitera, www.arkitera.com

[16] Çelikkol A.H., İstanbul Beyoğlu Tarlabaşı Yöresi Konutları Üzerine Bir Araştırma, Istanbul, 2009.

[17] Mimarizm, www.mimarizm.com

[18] Harvey, D., Class Structure and the Theory of Residential Differentiation: The Urban Experience, Blackwell, UK, 1992.

[19] De Certaue M., Walking in the City: The Practice of Everyday Life, France, 1980.

[20] Brebbia, C.A., Ozcevik, O., Sener, S.M., Sustainable Development and Planning, UK, 2015. 